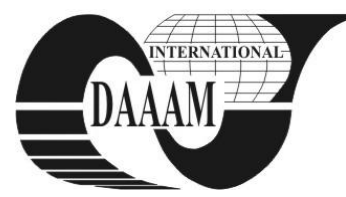

Annals of DAAAM for 2011 \& Proceedings of the 22nd International DAAAM Symposium, Volume 22, No. 1, ISSN 1726-9679 ISBN 978-3-901509-83-4, Editor B. Katalinic, Published by DAAAM International, Vienna, Austria, EU, 2011 Make Harmony between Technology and Nature, and Your Mind will Fly Free as a Bird Annals \& Proceedings of DAAAM International 2011

\title{
THE RATIONALIZATION OF THE PRODUCT LIFE CYCLE WITH THE ANALYZE OF EACH PHASE
}

\author{
KROTAK, S[tanislav] \& SIMLOVA, M[artina]
}

\begin{abstract}
The aim of this paper is to show a rationalization of the product suggestion together with its life cycle of Engineering Design Science knowledge and Project Management knowledge. It is possible to predicate characteristics which can be used during the design of a product thanks to the rationalization of the life cycle and the analysis of its single phases. The rationalization is used during the design of any product - the technical product. Making provision for the life cycle phases during the design phase enables an increase in product quality and a well arranged archiving of the documentation too
\end{abstract}

Key word: life cycle, product, construction, EDS, requirements

\section{INTRODUCTION}

Current society aims to produce many products on which many requirements are placed. It is necessary to ensure production, use and liquidation of products in the concept phase and product design phase. That is why the rationalization of the product design in terms of its whole life cycle from Engineering Design Science (EDS) knowledge (Eder \& Hosnedl, 2010) with use of Project

Management knowledge (Němec, 2002) is suggested in this paper. For the rationalization of the suggestion it is very important to determine suboptimal correct requirements for each phase of the life cycle. The continuous classification of their predicated fulfilment is the basic feedback impedance manager instrument during the product design.

\section{THE PRODUCT LIFE CYCLE ACCORDING TO EDS}

The product life cycle as a technical system can be divided and defined according to various aspects. The segmentation according to transformation processes in the basic phase of the technical system life cycle appears for EDS needs and construction as optimal. Transformation systems that agree with transformation processes enable many important aspects to be implicated (e. g. transformation systems requirements for technological systems characteristics) in the specification of TS requirements, in TS classification and so on.

In all life cycle phases it is necessary to observe and to make provision for basic sectional requirements connected with operators that are not alluded to by each phase for simplification, like for example security, hygiene, ergonomics, ecology, economics, compliance with regulations and laws, patents, licences etc. A different expected quality of individual operators (especially human and technical means) can be implicated in each LC phase (e. g. in production or in operating phase etc.) (Eder \& Hosnedl, 2010). It is advantageous to design the product with the help of systematic specification of requirements on TS characteristics (Hosnedl, 2011).

\section{THE PRODUCT LIFE CYCLE ANALYSIS}

Each LC phase of the product (TS) (Fig. 1) that is necessary for a rational design is briefly described in this section. Processes, existence and effects of operators (Fig. 1) that are a resource of required effects must be respected in each LC phase. It is advantageous that always only 5 similar operators; human, technical system (technical means), active and reactive surroundings, informational and manager system are in compliance with EDS knowledge in each phase of LC TS.

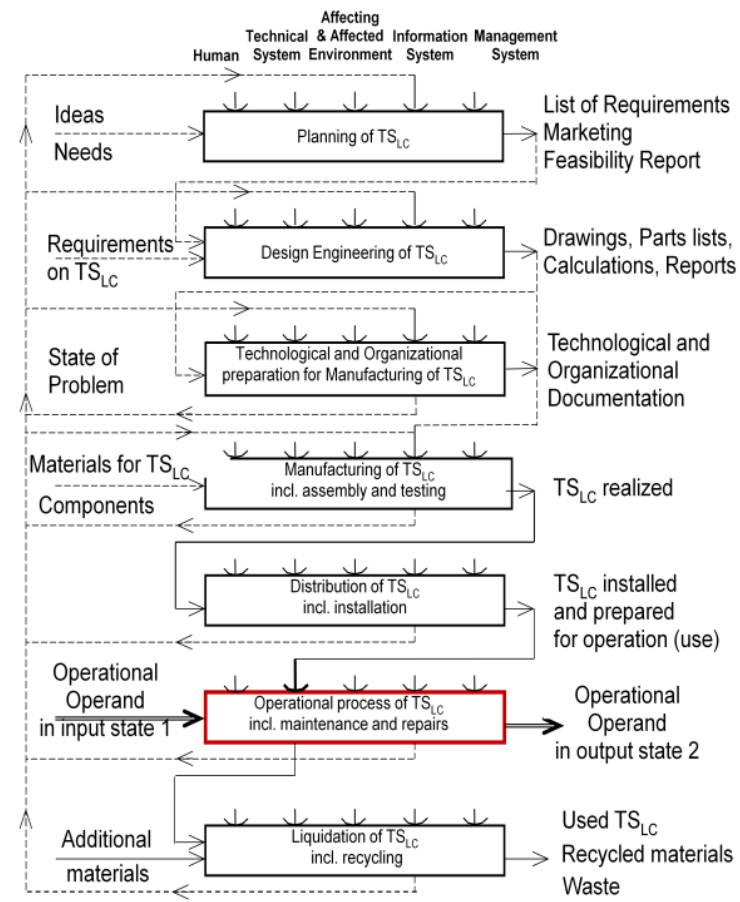

Fig. 1. The TS life cycle '- series of TrfP (with TrfS) in its main life phases (Hosnedl, 2011)

\subsection{Planning the beginning of TS}

During the planning comes to an exact hesitate of time needs, resources assignment (human, technological, material etc.) to particular processes and their operations (Rosenou, 2007). It is necessary to specify continuous costs and cash flow and to consider how the quality classification of a final TS will run. The planning process is shown in Fig. 2, in which 6 basic questions that are necessary to specify are listed (Němec, 2002).

Part of the planning should be predicting eventual risks which may arise during the project realisation. These risks will demand a suitable intervention (matching solution) that will demand specific time. That is why it is important to predicate risks in a project plan and to create time and cost (budget) reserves for their solution. 


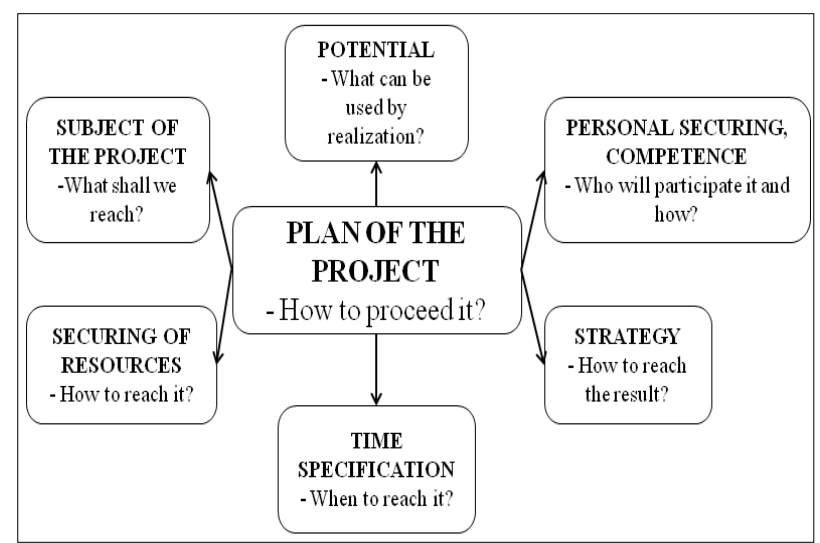

Fig. 2. Diagram of project planning (Němec, 2002)

\subsection{Design engineering of TS}

The second phase of the product LC in Fig. 1 can be demonstrated as a problem to solve together with EDS knowledge. It concerns a common action (Problem Solving) of the constructional process (Hosnedl, 2011) which is theoretically supported by the use of EDS knowledge, especially from the Theory of Technical Systems.

The aim of this is (Hosnedl, 2011) the rationalization of the TS suggestion with a goalseeking sequence pursuant to the methodology (technology) according to the EDS "map of knowledge". It is based on connections of particular transformations (operations) that lead to a demanded change of an operand input status on a required output status and pursuant to a system of theoretical and practical, however according to the theory of organized knowledge that are the background of this methodology.

\subsection{Technological and organizational preparation of the production and other phases of the TS life cycle}

The third phase of the product LC (Fig. 1) includes a set of technical (specific constructional, technological, organizational and economical) works and activities for a rational assuring of production and other processes in the LC of the suggested TS (size, characteristics, demanded material etc.) including technological processes and their accessories (machines, facilities, tools, instruments etc.) and a suitable filling of information systems (labour-consumption, costs etc.) (Křikač, 2004)

\subsection{The TS production including assembly, testing etc.}

The next phase of the product LC (Fig. 1) and its production can be shaped like a process of changing (transformation) the status of input operand to the output status (product) with the aim of implementing the required characteristics into a transformed semi-product. It can be a production of a single TS or of technical and technological means for production, distribution, service etc. of a TS.

\subsection{TS distribution including packaging, storage, installation, etc.}

Distribution as an important phase of the LC (Fig. 1Fehler! Verweisquelle konnte nicht gefunden werden.) must not be forgotten. It is necessary to include distribution during the design of the TS and during the planning of a project too. We must not produce a product which will be impossible to freight (for example we forget to make an eye for a crane), to guarantee against wear or mechanical damage by distribution or it will not be possible to import it to the place of operation.

\subsection{The TS operation including service, repairs etc.}

In this phase (Fig. 1) the required aims of the project are realised with the help of the TS operation. This phase is the most important from the view of the customer because the customer is mostly interested only in function and effectiveness of the product. Important processes which are necessary to connect to the process of planning and TS design are service, repairs etc.

\subsection{The TS liquidation including disassembly, separation, recycling etc.}

In this phase of the LC (Fig. 1) deals with not only the liquidation of the final product (output) but also with all tools used and means that do not have other uses. It also deals with shredding and liquidation of unnecessary documentation either directly after the accomplishment or after the predetermined time of storage.

\section{CONCLUSION}

Expectations for increasing the quality of a designed TS and at the same time for time and cost reduction for its realization and increasing its constructional competitiveness are created during planning and design of products (TS) with use of the transparent concept of their life cycle (LC). This is achieved relatively simply to predict all important situations during its LC. Thanks that it is possible to form competent requirements which must be respected during planning and construction TS. It is advantageous to use a systematic specification of requirements on TS characteristics including a classification their fulfilment because of well-arranged and compact documentation of these requirements. The systematic specification of requirements is necessary not only for suboptimalization of the construction process but also for suboptimalization of each characteristic TS including reducing the total time and cost demands etc.

The author is currently completing the realization of a prototype product designed with the use of the life cycle model. Existing classifications agree with the results that are formed in this conclusion.

\section{ACKNOWLEDGEMENTS}

This paper includes results from Project SGS-2010-049 Complex support of design engineering of technical products to improve their properties and competitiveness subsidised by the Czech Ministry of Education. We also want to thank to Prof. Ing. Stanislav Hosnedl, CSc. for his highly-valued advises.

\section{REFERENCES}

Eder, W. E.; Hosnedl, S. (2010). Introduction to Design Engineering: Systematic Creativity and Management. CRC Press / Balkema, Taylor \& Francis Group, Leiden, ISBN: 978-0-415-55557-9, The Netherlands

Hosnedl, S. (2011). Systémové navrhování technických produktů. Předmět KKS/ZKM. Podklady k přednáškám. ZČU, FST, KKS, Plzeň

Křikač, K. (2004). Organizace a ř́zení výroby, Metodická a studijní pomuicka. ISBN 80-7043-346, Plzeň

Němec, V. (2002). Projektový management. Grada Publishing, Praha

Rosenou, M. D. (2007). Řizení projektů. Brno: Computer Press 